\title{
DAMPAK KEBERADAAN OBJEK WISATA TEBING BREKSI TERHADAP KEHIDUPAN SOSIAL EKONOMI MASYARAKAT DI DESA SAMBIREJO, PRAMBANAN, KABUPATEN SLEMAN
}

Mona Erythrea Nur Islami ${ }^{1}$ dan Umiyati ${ }^{2}$

${ }^{1,2}$ Sekolah Tinggi Pariwisata AMPTA, Yogyakarta, Indonesia. Email:

\begin{tabular}{|c|}
\hline \\
Histori Artikel \\
Submitted: \\
05 Februari 2020 \\
Reviewed: \\
24 Februari 2020 \\
Accepted: \\
05 Maret 2020 \\
Published: \\
15 Mei 2020 \\
\hline
\end{tabular}

\begin{abstract}
ABSTRAK
Penelitian ini bertujuan untuk mengetahui kondisi sosial ekonomi masyarakat Desa Sambirejo sebelum dan sesudah adanya kegiatan wisata di Taman Wisata Tebing Breksi. Penelitian ini merupakan jenis penelitian kualitatif deskriptif untuk mendeskripsikan suatu keadaan atau fenomena. Metode pengambilan data menggunakan observasi dan wawancara kepada para pelaku yang terlibat langsung dalam kegiatan wisata di Tebing Breksi dan merasakan dampak ekonomi dan sosial dari adanya kegiatan wisata tersebut. Hasil penelitian menunjukan bahwa keberadaan Taman Wisata Tebing Breksi berdampak positif terhadap perubahan sosial dan ekonomi masyarakat Desa Sambirejo. Dari aspek ekonomi adalah kesempatan kerja dan peluang usaha yang
\end{abstract} besar, pendapatan masyarakat bertambah, pengelolaan berbasi CBT, dan percepatan pembangunan infrastruktur. Sedangkan dari aspek sosial adalah munculnya struktur mata pencaharian baru di bidang pariwisata, serta membawa transformasi tata nilai yang positif.

Kata kunci : Taman Wisata Tebing Breksi, Dampak Sosial dan Ekonomi,Desa Sambirejo.

\section{THE IMPACT OF TEBING BREKSI TOURISM OBJECT TO THE SOCIAL ECONOMIC LIFE OF THE COMMUNITY IN THE VILLAGE OF SAMBIREJO, PRAMBANAN, SLEMAN}

\begin{abstract}
The research aims to determine the socio economic conditions from the community in Sambirejo village before existing of tourism activities and after. The research is a qualitative study used to describe a situation or phenomenon. The method of collecting data uses observation and interviews with tourism actors directly involved in tourism activities on Tebing Breksi and are affected economically and socially. The result showed that the existence of Tebing Breksi had a positive effect on the socio-economic changes for the community of Sambirejo village. The economic impact is the creation of job and business opportunities, increased community income, CBT based management and accelerated infrastructure development. Sosial impact is the emergence of new livelihood structures in tourism and give positive value transformation.
\end{abstract}

Keywords : Tebing Breksi, Social economic impact, Sambirejo village 


\section{PENDAHULUAN}

Kegiatan pariwisata pada hakikatnya merupakan kegiatan yang sifatnya sementara, dilakukan secara suka rela dan tanpa paksaan untuk menikmati daya tarik wisata. Dalam perkembangannya industri pariwisata ini mampu berperan sebagai salah satu sumber pendapatan negara maupun daerah. Pariwisata sering dipersepsikan sebagai wahana untuk meningkatkan pendapatan, baik pendapatan daerah maupun pendapatan masyarakat daerah sekitar daya tarik wisata, terutama untuk meningkatkan pendapatan pemerintah, khususnya perolehan devisa, sehingga perkembangannya lebih bersifat ekonomi-sentris dan berorientasi pada pertumbuhan. Karena jumlah perolehan devisa ditentukan oleh jumlah kunjungan, pengeluaran, dan lama kunjungan wisata ke daerah

tujuan.(http://www.kemenpar.go.id/post/siara n-pers-pengarusutamaan-jadi-kunci-sukses- $p$ engembangan-sektor-pariwisata)

Salah satu provinsi di Indonesia yang memiliki daya tarik wisata potensial adalah Provinsi Daerah Istimewa Yogyakarta. Daerah Istimewa Yogyakarta memiliki empat kabupaten dan satu kota madya. Masing- masing dari kabupaten dan kota madya tersebut memiliki daya tarik wisata yang sangat potensial untuk dikembangkan menjadi sebuah destinasi wisata. Salah satu kabupaten yang memiliki daya tarik yang potensial adalah Kabupaten Sleman.

Kabupaten Sleman memiliki objek wisata alam, budaya, dan buatan. Salah satu objek wisata alam di Kabupaten Sleman yang menarik untuk dikunjungi adalah Tebing Breksi. Keberadaan objek wisata Tebing Breksi ini menghasilkan tanggapan yang beragam dari masyarakat Desa Sambirejo, hal ini dikarenakan objek wisata Tebing Breksi ini memanfaatkan bekas tambang batu breksi yang berhenti beroperasi pada tahun 2014. Tambang batu breksi ini sendiri merupakan sumber mata pencaharian masyarakat desa Sambirejo. Namun dengan berhentinya operasi penambangan batu breksi membuat ekonomi masyarakat desa
Sambirejo menurun, bahkan berdampak buruk bagi sebagian masyarakat. Hal ini dikarenakan sebagian masyarakat desa Sambirejo kehilangan mata pencaharian pokok sebagai penambang Batu Breksi.

Setelah penambangan batu breksi berhenti beroperasi, banyak masyarakat yang datang ke bekas tambang batu breksi ini hanya untuk menghabiskan waktu berfoto ria di bekas tambang batu breksi, tidak hanya berfoto semata masyarakat juga mengunggah hasil foto dari bekas tambang batu Breksi ini ke sosial media mereka masing-masing, dan mendapatkan respon dari pengguna sosial media lainnya. Masyarakat Desa Sambirejo melihat adanya potensi yang dapat dikembangkan menjadi sebuah objek wisata yang akan mampu menopang perekonomian masyarakat.

Masyarakat berinisiatif untuk mengembangkan bekas tambang batu breksi ini dengan cara memahat menjadi ukiran indah dibekas tambang batu Breksi. Saat ini objek wisata Tebing Breksi mulai banyak diminati oleh wisatawan. Wisatawan yang berkunjung tidak hanya berasal dari wilayah Yogyakarta saja, melainkan dari luar provinsi Yogyakarta. Berdasarkan hasil wawancara yang peneliti dapatkan dari kepala dukuh Dusun Ngelengkong, kondisi yang demikian ini mampu memberikan dampak yang positif terhadap sosial ekonomi masyarakat Desa Sambirejo serta mampu meningkatkan kesejahteraan masyarakat Desa Sambirejo. Kegiatan pariwisata di Tebing Breksi ini menimbulkan berbagai dampak yang dihasilkan dari interaksi masyarakat sekitar objek wisata Tebing Breksi dengan wisatawan yang datang berkunjung.

Dampak sosial yang terjadi di Desa Sambirejo ini antara lain adalah perubahan aspek demografi atau kepadatan penduduk yang terjadi di desa Sambirejo terutama di kawasan objek wisata Tebing Breksi. Kawasan objek wisata Tebing Breksi, mulai dipadati oleh pendatang baru yang memulai usaha berdagang di kawasan Tebing Breksi untuk menyediakan kebutuhan wisatawan. 
yang secara langsung mengubah struktur mata pencaharian masyarakat desa Sambirejo yang awalnya berprofesi sebagi pengarit (tukang arit makanan hewan ternak) menjadi pedagang dan karyawan.

Selain berprofesi sebagai pedagang dan karyawan di objek wisata Tebing Breksi, masyarakat juga membuat komunitas-komunitas yang menawarkan jasa berupa jasa pengambilan foto dan jasa penyediaan spot foto, Sehingga terbentuk komunikasi antara masyarakat desa Sambirejo baik yang berprofesi sebagai pedagang, karyawan, maupun penyedia jasa dengan wisatawan. Berdasarkan pengamatan yang dilakukan oleh peneliti, dari komunikasi yang terjadi antara masyarakat Desa Sambirejo dengan wisatawan ini berpengaruh juga terhadap nilai sosial masyarakat desa Sambirejo. Hal ini diakibatkan oleh pergeseran perilaku, gaya berbicara dan gaya hidup masyarakat Desa Sambirejo yang mulai meniru dan mengikuti perilaku, gaya berbicara dan gaya hidup wisatawan terutama untuk kalangan ibu-ibu dan para remaja desa Sambirejo sehingga berdampak terhadap perubahan kehidupan sosial masyarakat desa Sambirejo.

Selain berdampak pada perubahan kehidupan sosial, keberadaan objek wisata Tebing Breksi juga menimbulkan dampak terhadap perubahan perekonomian masyarakat desa Sambirejo, yaitu dampak terhadap peningkatan pendapatan masyarakat dengan cara berdagang di Kawasan Tebing Breksi, dampak terhadap kesempatan kerja sebagai karyawan dalam pengelolaan dan pengembangan Tebing Breksi, dampak terhadap harga makanan dan minuman serta tarif penggunaan jasa komunitas yang dibentuk oleh masyarakat desa Sambirejo, dampak terhadap pembangunan infrastruktur dan akomodasi lainnya di kawasan objek wisata Tebing Breksi, dan dampak terhadap pajak untuk pemerintah. Oleh karena itu, keberadaan objek wisata Tebing Breksi mampu meningkatkan kesejahteraan ekonomi masyarakat sekitar objek wisata Tebing Breksi.
Alasan inilah yang membuat peneliti tertarik untuk melakukan penelitian mengenai perubahan sosial ekonomi pada masyarakat terdampak. Dengan permasalahan yang ada peneliti membuat judul penelitian dengan judul "Dampak Keberadan Objek Wisata Tebing Breksi Terhadap Perubahan Sosial Ekonomi Masyarakat Desa Sambirejo, Prambanan, Kabupaten Sleman".

\section{LITERATURE REVIEW}

Daya tarik wisata menurut Direktoral Jenderal Pemerintahan Pariwisata dibagi menjadi tiga macam, yaitu daya tarik wisata alam, daya tarik wisata budaya dan daya tarik wisata buatan.

Daya tarik wisata alam adalah sumber daya alam yang berpotensi serta memiliki daya tarik bagi pengunjung baik dalam keadaan alami maupun setelah usaha budi daya. Daya tarik wisata sosial budaya dapat dimanfaatkan dan dikembangkan sebagai objek dan daya tarik wisata meliputi museum, peninggalan sejarah, upacara adat, seni pertunjukan dan kerajinan. Daya tarik wisata minat khusus merupakan jenis wisata yang baru dikembangkan di Indonesia, wisata ini lebih diutamakan pada wisatawan yang mempunyai motivasi khusus. Dengan demikian, biasanya para wisatawan harus memiliki keahlian. Contohnya berburu, mendaki gunung, arung jeram, tujuan pengobatan, agrowisata dan lainnya.

\section{Dampak}

Pengertian dampak menurut Kamus Besar Bahasa Indonesia adalah benturan, pengaruh yang mendatangkan akibat baik positif maupun negatif. Pengaruh adalah daya yang ada dan timbul dari sesuatu (orang, benda) yang ikut membentuk watak, kepercayaan atau perbuatan seseorang. Pengaruh adalah suatu keadaan dimana ada hubungan timbal balik atau hubungan sebab akibat antara apa yang mempengaruhi dengan apa yang dipengaruhi. Menurut Soerjono Soekamto (2006), dampak diartikan sebagai penggunaan konsep dasar untuk menelaah 
sebuah gejala sosial dalam artian dampak sosial merupakan efek dari fenomena sosial yang terjadi dalam kehidupan masyarakat.

Dampak secara umum terbagi menjadi dua, yaitu dampak biotik pada lingkungan hidup mencakup seluruh makhluk hidup didalamnya, yakni manusia, hewan, tumbuhan, dan benda hidup lainnya. Sedangkan dampak abiotik adalah benda-benda mati yang bermanfaat bagi kelangsungan hidup disebuah lingkungan yakni mencakup tanah, air, api, batu, dan udara. Dalam penelitian ini peneliti melakukan penelitian terhadap dampak biotik lingkungan yakni mengenai dampak sosial dan ekonomi masyarakat di Desa Sambirejo.

Dampak secara sederhana dapat diartikan sebagai pengaruh atau akibat. Dalam setiap kegiatan pariwisata akan menimbulkan pengaruh atau akibat dari interaksi yang terjadi antara pelaku usaha dengan wisatawan. Seperti yang terjadi di Desa Sambirejo pengaruh atau dampak yang ditimbulkan dari interaksi antara masyarakat dengan wistawan adalah dampak sosial dan dampak ekonomi.

\section{Dampak Ekonomi}

Pariwisata di suatu daerah sangat berpengaruh pada perkembangan ekonomi daerah wisata tersebut. Hal ini karena disebabkan oleh kegiatan pariwisata itu secara langsung menyentuh dan melibatkan masyarakat, sehingga membawa dampak terhadap masyarakat setempat.

Delapan kelompok besar dampak pariwisata terhadap kondisi ekonomi, yaitu : (1) Dampak terhadap pendapatan masyarakat; (2) Dampak terhadap kesempatan kerja; (3) Dampak terhadap harga-harga; (4) Dampak terhadap distribusi manfaat/keuntungan; (5) Dampak terhadap kepemilikan dan kontrol; (6) Dampak terhadap pembangunan pada umumnya; (7) Dampak terhadap pendapatan pemerintah (Cohen dalam Pitana dan Gayatri, 2005; Fyka, S. A. dkk., 2018; Darwan, D., dkk, 2019; Wahyudy, S. N. 2019).

Menurut Departemen Kebudayaan dan
Pariwisata RI (2005) dalam Sapta (2011), menjelaskan bahwa pembangunan kepariwisataan pada dasarnya ditujukan untuk beberapa tujuan pokok yang dapat dijelaskan sebagai berikut salah satunya adalah peningkatan Ekonomi dan Industri.

Pengelolaan kepariwisataan yang baik dan berkelanjutan diharapkan mampu memberikan kesempatan bagi tumbuhnya ekonomi di suatu destinasi pariwisata. Penggunaan bahan dan produk lokal dalam proses pelayanan di bidang pariwisata juga akan memberikan kesempatan pada industri lokal untuk berperan dalam penyediaan barang dan jasa.

\section{Dampak Sosial}

Pengaruh atau akibat dari suatu kejadian, keadaan, kebijakan sehingga mengakibatkan perubahan baik yang bersifat positif maupun yang bersifat negatif bagi lingkungan sosial dan keadaan sosial. Dampak sosial yang ditunjukan akibat adanya pariwisata adalah perubahan sosial masyarakat. Sebelum terjadi perubahan sosial didahului dengan adanya interaksi. Menurut Bimo Walgito (2003), interaksi sosial merupakan suatu hubungan antara individu satu dengan individu lainnya dimana individu yang satu dapat mempengaruhi individu yang lainnya sehingga terdapat hubungan timbal balik.

Menurut I Gusti Bagus ( 2015), mengklasifikasikan aspek dampak sosial yaitu: (1) Dampak terhadap aspek demografis adalah meningkatnya jumlah penduduk yang tinggal didaerah sekitar kawasan obyek wisata sehingga terjadi kepadatan penduduk khususnya di daerah yang terdapat kegiatan atau aktivitas wisata; (2) Dampak terhadap struktur mata pencaharian (perubahan pekerjaan) peluang kerja di sektor pariwisata cukup menarik, hal ini dikarenakan beberapa jenis pekerjaan yang tidak memerlukan keahlian khusus di sektor pariwisata, seperti tukang parkir, ticketing, petugas keamanan, penyedia jasa makanan minuman, dan lainnya akan menarik minat para petani dan ibu rumah tangga untuk bekerja di sektor pariwisata; (3) Dampak terhadap solidaritas penduduk dimana timbulnya solidaritas antar 
masyarakat sangat kental sehingga terjadi interaksi sosial baik antara masyarakat dengan masyarakat, masyarakat dengan pengelola wisata, maupun masyarakat dengan wisatawan. Fakta nyata dari dampak terhadap mobilitas penduduk adalah terbentuknya komunitas-komunitas yang menawarkan jasa berupa jasa pengambilan foto dan penyediaan spot foto, yang dibentuk oleh para pemuda-pemuda Desa Sambirejo; (4) Dampak terhadap nilai sosial (bahasa, perilaku, dan gaya hidup), pergeseran perilaku, gaya berbicara(bahasa), dan gaya hidup tidak dapat dihindarkan dalam dinamika pariwisata. Pengaruh wisatawan dalam interaksinya dengan pelaku wisata dan masyarakat sangat kental karena setiap hari bersinggungan dan mengamati perilaku wisatawan, seperti yang terjadi kepada masyarakat Desa Sambirejo terutama para pedagang yang lebih banyak ibu-ibu dan remaja ini mulai banyak meniru dan mengikuti perilaku, gaya berbicara dan gaya berpakaian wisatawan sehingga berdampak terhadap nilai sosial masyarakat.

\section{Pengertian Masyarakat}

Masyarakat dalam istilah bahasa inggris adalah society yang berasal dari bahasa latin socius yang berarti (kawan). Istilah masyarakat berasal dari kata bahasa arab syaraka yang berarti (ikut serta dan berpartisipasi). Masyarakat adalah sekumpulan manusia yang saling bergaul, dalam istilah ilmiah adalah saling berinteraksi. Suatu kesatuan manusia dapat mempunyai prasarana melalui warga-warganya dapat saling berinteraksi.

Definisi lain, masyarakat adalah kesatuan hidup manusia yang berinteraksi menurut suatu sistem adat istiadat tertentu yang bersifat kontinyu, dan yang terikat oleh suatu rasa identitas bersama. Komunitas merupakan kesatuan masyarakat yang memiliki keempat ciri yaitu : (1) Interaksi antar warga-warganya; (2) Adat istiadat; (3) Kontinuitas waktu; (4) Rasa identitaas kuat yang mengikat semua warga (Koentjaraningrat, 2009). Semua warga masyarakat merupakan manusia yang hidup bersama atau hidup dalam suatu tatanan pergaulan dan keadaan ini akan tercipta apabila manusia melakukan hubungan

\section{METODE PENELITIAN}

\section{Lokasi dan Waktu Penelitian}

Lokasi penelitian ini dilaksanakan di Taman Wisata Tebing Breksi, Desa Sambirejo, Kecamatan Depok, Kabupaten Sleman. Penelitian telah dilakukan pada bulan Mei 2019 untuk mendapatkan data yang sesuai untuk mendukung penelitian. Alasan peneliti melakukan penelitian di Taman Wisata Tebing Breksi, karena Taman Wisata Tebing Breksi merupakan salah satu objek wisata baru di Kabupaten Sleman yang banyak dikunjungi wisatawan nusantara, sehingga diasumsikan Taman Wisata Tebing Breksi seharusnya memberikan dampak yang positif terhadap masyarakat Desa Sambirejo.

\section{Teknik Pengumpulan Data}

Dalam penelitian kualitatif untuk memperoleh informasi yang mendalam mengenai fokus penelitian, maka peneliti menggunakan teknik cuplikan (sampling) yaitu purposive sample atau sampel bertujuan. Menurut Afifudin (2009: 130), teknik purposive sample adalah sampel yang dipilih bergantung pada tujuan penelitian tanpa memperhatikan kemampuan generalisasinya.

Pengumpulan data merupakan langkah penting dalam metode ilmiah. Pengumpulan data menurut Sugiyono (2014) dapat dilakukan dengan berbagai setting, berbagai sumber, dan berbagai cara dalam upaya mengumpulkan data.

Beberapa informasi yang diperoleh dari hasil observasi adalah ruang (tempat), pelaku, kegiatan, objek, perbuatan, kejadian atau peristiwa, waktu dan perasaan. Alasan peneliti melakukan observasi adalah untuk menyajikan gambaran realistik perilaku atau kejadian, untuk menjawab pertanyaan, guna mengerti perilaku manusia, dan untuk evaluasi yaitu melakukan pengukuran 
terhadap aspek tertentu, melakukan umpan balik terhadap pengukuran.

Observasi pasif ( passive observation ) adalah metode pengumpulan data yang digunakan untuk menghimpun data penelitian melalui pengamatan dan pengindraan dimana peneliti hanya datang ketempat kegiatan orang yang diamati, tetapi tidak ikut terlibat dalam kegiatan tersebut.

Alasan peneliti menggunakan jenis observasi pasif (passive observation) untuk mengumpulkan data dengan jalan mengadakan pengamatan terhadap kegiatan yang sedang berlangsung. Observasi merupakan penelitian yang dilakukan secara sistematis dan sengaja dilakukan dengan indra penglihatan untuk melihat kejadian yang berlangsung secara langsung pada saat kejadian itu berlangsung. Dalam penelitian ini observasi digunakan untuk mendapatkan data aktual, dalam artian data yang dikumpulkan pada saat peristiwa berlangsung sehingga peneliti memperoleh gambaran dan mampu memahami bagaimana dampak sosial dan ekonomi yang terjadi di Desa Sambirejo dari keberadaan Taman Wisata Tebing Breksi.

Dalam observasi yang peneliti lakukan, peneliti melihat secara langsung aktivitas yang terjadi antara masyarakat Desa Sambirejo yang menjadi pelaku wisata di Taman Wisata Tebing Breksi dengan wisatawan. Dimana dari adanya kegiatan wisata dan aktivitas wisata di Tebing Breksi ini memberikan dampak terhadap kondisi baik sosial maupun ekonomi terhadap masyarakat Desa Sambirejo.

Teknik wawancara yang digunakan oleh peneliti adalah wawancara semiterstruktur dimana informan bebas dalam mengemukakan pendapat dan ide-idenya tentang dampak keberadaan objek wisata Tebing Breksi terhadap perubahan sosial ekonomi masyarakat desa Sambirejo.

Dalam penelitian ini peneliti mengambil jumlah informan 25 orang yang terlibat langsung dalam aktivitas wisata di Taman Wisata Tebing Breksi dan dinilai memiliki informasi mengenai dampak yang dirasakan dari keberadaan Taman Wisata Tebing Breksi, adapun yang menjadi informan penelitian terdiri dari : (1) Bapak Ahmadi selaku kepala Dukuh yang mengetahui perubahan sosial dan ekonomi masyarakat desa Sambirejo; (2) Kholiq selaku ketua pengelola Taman Wisata Tebing Breksi, adalah informan yang memiliki data lengkap mengenai data para pengelola di Taman Wisata Tebing Breksi; (3) Ketua POKDARWIS dan anggota POKDARWIS Desa Sambirejo, merupakan perintis Taman Wisata Tebing Breksi yang memiliki data lengkap bagaimana alihfungsi Tebing Breksi menjadi obyek wisata; (4) Karyawan Tebing Breksi yang meliputi petugas keamanan, petugas retribusi, petugas lalu lintas, komunitas penyedia spot foto. Karena informan tersebut merupakan masyarakat yang mengalami dampak sosial dan ekonomi dari kegiatan wisata di Taman Tebing Breksi; (5) Pedagang di sekitar objek wisata Tebing Breksi yang berperan sebagai penyedia jasa makanan dan minuman yang merasakan langsung dampak sosial dan ekonomi keberadaan Taman Wisata Tebing Breksi.

Menurut Sugiyono, dokumentasi dapat berbentuk tulisan, gambar, atau karya-karya monumental seseorang, selain itu hasil penelitian juga partisipasif ini akan lengkap, tajam dan sampai mengetahui pada tingkat makna dari setiap perilaku yang nampak(Sugiyono, 2014). Peneliti mengambil gambar atau foto yang sesuai dengan kebutuhan data untuk melengkapi penulisan penelitian. Peneliti melakukan dokumentasi-dokumentasi yang dapat mendukung pengumpulan data pada obyek yang diteliti dengan pengambilan gambar untuk melengkapi penelitian di Taman Wisata Tebing Breksi.

Studi kepustakaaan dilakukan dengan cara mencari referensi yang diperoleh dengan cara membaca buku-buku tersebut, baik dari media cetak maupun media elektronik. Dalam penelitian ini studi kepustakaan yang dipelajari mengenai dampak keberadaan obyek wisata terhadap sosial ekonomi 
masyarakat

\section{HASIL DAN PEMBAHASAN}

\section{Profil Taman Wisata Tebing Breksi}

Tebing breksi merupakan salah satu tempat wisata baru di Yogyakarta khususnya di Kabupaten Sleman yang berhasil menarik perhatian masyarakat. Awal mula tebing ini hanyalah sebuah tambang batu biasa yang menyerupai bukit-bukit kecil. Selain eksotis, Tebing breksi juga menawarkan pemandangan lanskape yang luar biasa. Dari atas tebing, wisatawan dapat melihat Candi Prambanan, Candi Sowijan dan Candi Barong yang dilatari oleh gagahnya Merapi. Tak hanya itu tebing ini pun menawarkan panorama senja yang menggoda.

Bertahun-tahun Tebing Breksi di Pedukuhan Ngelengkong, Groyokan Desa Sambirejo menjadi sumber mata pencaharian masyarakat Desa Sambirejo. Mereka menambang dan memperoleh pendapatan dari kegiatan menambang batu Breksi, namun pada akhir tahun 2014 penambangan tersebut harus dihentikan. Hal ini dikarenakan keluarnya larangan pemerintah setelah sejumlah peneliti melakukan kajian di Tebing Breksi. Hasilnya, batuan kapur Breksi adalah hasil erupsi abu vulkanik dari Gunung Api Purba Ngelanggeran, maka kawasan ini masuk dalam cagar budaya dan harus dilestarikan. Sama halnya dengan keberadaan Gunung Api Purba Ngelanggeran, Candi Ijo, Situs Ratu Boko dan sebagainya, Tebing Breksi juga merupakan salah satu bukti sejarah pembentukan pulau jawa. Dari hasil penelitian-penelitian kemudian mendorong penetapan Kawasan Tebing Breksi sebagai bagian dari warisan geologis/geoheritage melalui Keputusan Kepala Badan Geologi Republik Indonesia Nomor 1157.K/40/BGL/2014, setelah menjadi menjadi kawasan geoheritage warga masyarakat Desa Sambirejo tidak bisa lagi menggantungkan hidup sebagai penambang batu. Sebagai pemangku kebijakan, Bapak Gubernur Daerah Istimewa Yogyakarta mendorong pengembangan wisata kawasan batu breksi ini untuk membantu masyarakat melalui Dinas Pariwisata Provinsi dan Dinas Pariwisata Kabupaten Sleman.

Saat ini, Tebing Breksi atau yang lebih dikenal dengan Taman Tebing Breksi sudah ditetapkan sebagai kawasan cagar budaya dan diresmikan langsung oleh Gubernur Daerah Istimewa Yogyakarta Sri Sultan Hamengku Buwono X. Pada tanggal 30 Mei 2015 merupakan momen tak terlupakan bagi masyarakat Desa Sambirejo, ribuan elemen masyarakat dari berbagai komunitas hadir menyaksikan Bapak Gubernur Sri Sultan Hamengku Buwono $X$ meresmikan panggung terbuka yang disebut Amphiteater, sekaligus menetapkan kawasan tebing breksi sebagai destinasi wisata.

Semenjak ditetapkannya Tebing Breksi sebagai kawasan wisata masyarakat Desa Sambirejo mulai bahu-membahu untuk mengembangkan dan melestarikan Tebing Breksi untuk menjadi lebih baik lagi, hal ini dibuktikan dengan prestasi Taman Wisata Tebing Breksi sebagai objek wisata terpopuler pada tahun 2018, dan di tahun yang sama Komunitas POKDARWIS Tlatar Seneng Desa Sambirejo mendapat penghargaan sebagai komunitas POKDARWIS terbaik se-Daerah Istimewa Yogyakarta.

\section{Kondisi Sosial dan Ekonomi Masyarakat Desa Sambirejo sebelum ada Taman Wisata Tebing Breksi}

Desa Sambirejo merupakan salah satu desa yang berada di Kecamatan Prambanan. Masyarakat Desa Sambirejo memiliki kesamaan ciri dengan desa-desa pada umumnya, memiliki kecenderungan yang sulit untuk diubah karena sudah tertanam sejak lama. Sama halnya dengan kondisi sosial dan ekonomi masyarakat Desa Sambirejo pada Tahun 1980-2014, dimana masyarakat menggantungkan hidup pada pekerjaan menjadi buruh, petani, dan penambang batu breksi yang kini dikelola menjadi sebuah taman wisata.

Keberadaan tebing batu Breksi yang dikelola menjadi Taman Wisata Tebing Breksi ini 
diharapkan membawa perubahan terhadap kondisi sosial dan ekonomi masyarakat Desa Sambirejo, dimana sebelumnya masyarakat Desa Sambirejo mayoritas bermata pencaharian sebagai buruh, petani, dan penambang batu breksi, selain itu masyarakat Desa Sambirejo juga didominasi oleh para Ibu Rumah Tangga (IRT) yang tidak memiliki pekerjaan hal ini dikarenakan kurang tersedianya lapangan kerja di Desa Sambirejo.

Kehidupan bermasyarakat warga Desa Sambirejo masih sangat kental, dimana sikap gotong royong masih terjalin dengan baik hal ini dibuktikan dengan adanya masyarakat yang masih melakukan pertemuan-pertemuan antar RT dan RW untuk menjalin kerukunan masyarakat desa.

Berbicara tentang kondisi sosial masyarakat Desa Sambirejo, tentunya juga berbicara tentang nilai sosial masyarakat, dimana saat masyarakat berprofesi sebagai petani, buruh, dan penambang ternyata sangat berpengaruh terhadap bahasa, gaya busana dan gaya hidup masyarakat Desa Sambirejo. Masyarakat Desa Sambirejo memiliki gaya berbicara yang kental, hal ini dikarenakan lingkungan saat terjadi komunikasi masyarakat menggunakan bahasa jawa yang merupakan bahasa yang sudah mereka pelajari sejak lahir, sehingga sedikit sulit saat diajak berkomunikasi menggunakan Bahasa Indonesia.

Selain gaya bahasa yang kental, profesi masyarakat sebagai penambang batu Breksi juga berpengaruh terhadap gaya hidup masyarakat Desa Sambirejo, yang sudah terbiasa dengan kondisi tidak memakai alas kaki pada saat melakukan penambangan batu breksi, terbiasa tidak menggunakam pakaian yang bagus atau bahkan tidak menggunakan baju dan tidak terbiasa tersenyum ramah pada sesama pekerja ataupun masyarakat lainnya. Selain itu pendapatan yang tidak dapat diperkirakan, dan juga kesulitan untuk mengatur keluar masuknya uang hasil dari kerja keras perhari mendorong mereka untuk berfoya-foya guna memuaskan letih setelah bekerja berat seharian, sehingga uang yang didapat dari bekerja setiap harinya langsung habis dalam waktu satu hari saja.

Sedangkan untuk kondisi ekonomi, masyarakat Desa Sambirejo mayoritas berprofesi sebagai petani, buruh, dan penambang, sebagai mata pencaharian. Selain itu, sebagian masyarakat Desa Sambirejo yang tidak memiliki pekerjaan, misalnya Ibu Rumah Tangga (IRT), anak-anak balita dan yang masih menempuh pendidikan, serta Lansia. Keberadaan Taman Wisata Tebing Breksi diharapkan mampu meningkatkan pendapatan masyarakat Desa Sambirejo. Keberadaan Taman Wisata Tebing Breksi ini juga membawa harapan baru bagi para Ibu Rumah Tangga untuk membantu perekonomian keluarga.

Masyarakat Desa Sambirejo yang sejak dulu sudah mulai membuka usaha dan jasa makan minum di luar Taman Wisata Tebing Breksi, mematok harga dagangan dengan harga yang normal sama seperti usaha jasa, makanan dan minuman di tempat lainnya, dimana usaha dagang masyarakat dipatok dengan harga standar.

Pembangunan di Desa Sambirejo pada saat sebelum ada Taman Wisata Tebing Breksi juga terbilang tidak ada pembangunanpembangunan yang terjadi. Sehingga akses jalan utama Sambirejo saat itu rusak dan sempit, sehingga membuat pengendara motor ataupun mobil harus berkendara dengan sangat hati-hati. Sama halnya dengan akomodasi tidak ada pembangunan akomodasi seperti restoran, penginapan, Balkondes dan lain-lain. Hal ini tentunya merupakan kondisi yang akan sulit berubah jika tidak ada keinginan yang kuat dari masyarakat untuk meningkatkan taraf hidup yang lebih baik, selain itu pemerintah diharapkan lebih banyak mengadakan kegiatan-kegiatan atau penyuluhan yang bertujuan untuk menjadikan masyarakat sadar wisata.

\section{Analisis Dampak Sosial di Desa Sambirejo setelah ada Taman Wisata Tebing Breksi}

\section{Dampak Sosial}

Dampak terhadap struktur populasi 
Perubahan sosial merupakan akibat dari suatu kejadian, keadaan, kebijakan sehingga mengakibatkan perubahan baik yang bersifat positif maupun yang bersikap negatif bagi lingkungan sosial dan keadaan sosial masyarakat. Salah satu aspek yang menyebabkan perubahan sosial adalah perubahan struktur populasi atau kepadatan penduduk yang terjadi akibat dari aktivitas kegatan wisata di Taman Wisata Tebing Breksi. Aktivitas kegiatan wisata Taman Wisata Tebing Breksi hingga saat ini masih mengutamakan tenaga dari masyarakat Desa Sambirejo dalam mengelola dan mengembangkan Taman Wisata Tebing Breksi. Sampai saat hanya ada 3\% pekerja dari luar Desa Sambirejo yang bekerja sebagai karyawan di Taman Wisata Tebing Breksi, pekerja dari luar Desa Sambirejo inipun tidak menetap sebagai penduduk di DesaSambirejo sehingga tidak ada pertambahan penduduk di Desa Sambirejo. 97\% sisanya merupakan masyarakat Desa Sambirejo dengan tingkat pendidikan yang beragam, mulai dari yang tidak menempuh pendidikan hingga tingkat pendidikan Diploma terlibat dalam aktivitas pariwisata di Taman Wisata Tebing Breksi. Dari hasil analisis data ditemukan hasil bahwa saat ini perubahan struktur populasi di Desa Sambirejo tidak terlalu signifikan atau hampir tidak ada perubahan struktur populasi atau kepadatan penduduk. Hal ini dikarenakan oleh sistem pengembangan yang berbasis masyarakat atau Community Bassed Tourism (CBT), dimana hanya ada beberapa masyarakat dari luar Desa Sambirejo yang membuka usaha dagang di kawasan Taman
Wisata Tebing Bereksi namun tidak menetap di Desa Sambirejo, sehingga tidak terjadi perubahan struktur populasi masyarakat atau kepadatan penduduk. Perubahan yang tidak terlalu signifikan ini berdampak positif terhadap masyarakat lokal Desa Sambirejo, yaitu peluang kerja dan peluang usaha dapat dimaksimalkan oleh masyarakat Desa Sambirejo.

Transformasi/perubahan struktur mata pencaharian

Aktivitas wisata yang terjadi dengan keberadaan Taman Wisata Tebing Breksi sangat berdampak terhadap perubahan struktur mata pencaharian masyarakat Desa Sambirejo. Kesempatan kerja di sektor pariwisata yang ada di Taman Wisata Tebing Breksi yaitu sebagai pengelola Taman Wisata Tebing Breksi, POKDARWIS, petugas parkir, petugas retribusi, petugas keamanan, dan lain-lain. Sedangkan peluang usaha baru di Desa Sambirejo yaitu sebagai pedagang kuliner, pedagang kaki lima, dan photobooth. (Sumber : Kholiq Widiyanto, Ketua Pengelola Taman Wisata Tebing Breksi, 2019).

Kesempatan kerja dan peluang usaha yang ada di Taman Wisata Tebing Breksi bersifat pekerjaan tetap sebagian masyarakat Desa Sambirejo, sehingga menimbulkan perubahan struktur mata pencaharian masyarakat Desa Sambirejo. Karena masyarakat yang dulunya berprofresi sebagai penambang, supir truk batu, dan pekerja di tambang batu breksi beralih pekerjaan menjadi pelaku pariwisata di Taman Wisata Tebing Breksi

Tabel 1

Transformasi Struktur Mata Pencaharaian Masyarakat

\begin{tabular}{|c|c|c|}
\hline No & Sebelum & Sesudah ada Wisata Tebing Breksi \\
\hline 1 & Penambang & $\begin{array}{l}\text { Pengelola,pedagang kuliner, petugas kebersihan, petugas parkir, } \\
\text { pekerja Bangunan/pemahat }\end{array}$ \\
\hline 2 & Jasa foto di malioboro & Penyedia spot foto, dan penyedia jasa Foto \\
\hline 3 & Supir truck batu & $\begin{array}{l}\text { Ketua pengelola, supir jeep, petugas Keamanan, petugas layout, } \\
\text { ticketing }\end{array}$ \\
\hline 4 & Karyawan pabrik & Pedagang kuliner, penyedia spot foto, dan usaha dagang, balkondes \\
\hline 5 & Petani & Pedagang kaki lima, petugas keamanan, Petugas kebersihan \\
\hline
\end{tabular}


Dari data diatas dapat dianalisis bahwa terjadi perubahan struktur mata pencaharian bagi sebagian masyarakat Desa Sambirejo. Hal ini membuktikan bahwa keberadaan Taman Wisata Tebing Breksi memberikan dampak yang positif terhadap perubahan struktur mata pencaharian masyarakat.

Berikut peneliti menyertakan data jumlah pekerja di Tebing Breksi sebelum menjadi objek wisata dan sesudah menjadi objek wisata:

Tabel 2

Tabel jumlah pekerja sebelum dan sesudah Tebing Breksi menjadi obyek wisata.

\begin{tabular}{|c|c|c|c|}
\hline $\begin{array}{l}\text { Sebelum } \\
\text { Menjadi } \\
\text { Obyek } \\
\text { Wisata }\end{array}$ & $\begin{array}{l}\text { Jumlah sebelum } \\
\text { menjadi Taman } \\
\text { Wisata } \\
\text { Tebing Breksi }\end{array}$ & $\begin{array}{l}\text { Setelah Menjadi Obyek } \\
\text { Wisata }\end{array}$ & $\begin{array}{l}\text { Jumlah setelah menjadi } \\
\text { Taman Wisata Tebing } \\
\text { Breksi }\end{array}$ \\
\hline Penambang & 40 orang & $\begin{array}{l}\text { Pengelola (Pokdarwis, petugas } \\
\text { keamanan, kebersihan, } \\
\text { retribusi/ticketi } \\
\text { ng, keindahan) }\end{array}$ & 90 orang \\
\hline $\begin{array}{l}\text { Tukang angkat batu } \\
\text { ke mobil }\end{array}$ & 10 orang & Pedagang kuliner & 60 orang \\
\hline \multirow{7}{*}{$\begin{array}{l}\text { Supir truck } \\
\text { batu }\end{array}$} & 10 orang & Pedagang kaki lima & 40 orang \\
\hline & & Supir jeep & 95 orang \\
\hline & & Fotobooth & 25 orang \\
\hline & & Penyedia ATV & 23 orang \\
\hline & & Balkondes & 20 orang \\
\hline & & Pekerja bangunan & 20 orang \\
\hline & & Fotographer & 5 orang \\
\hline
\end{tabular}

Sumber: Ketua Pokdarwis Tlatar Seneng dan Sekretaris Desa Sambirejo, (2019)

Transformasi struktur mata pencaharian yang terjadi di Desa Sambirejo cukup signifikan, hal ini diketahui dari tabel jumlah pekerja di Tebing Breksi sebelum menjadi Taman Wisata dan setelah menjadi Taman Wisata Tebing Breksi. Jumlah pekerja yang berprofesi sebagai penambang Batu Breksi awalnya hanya 40 orang, namun setelah menjadi Taman Wisata muncul berbagai pekerjaan baru seperti Pengelola Taman Wisata Tebing Breksi (Pokdarwis, petugas keamanan, kebersihan, retribusi/ticketing) pekerja di bertambah menjadi 90 orang.

Masyarakat Desa Sambirejo yang bekerja sebagai tukang angkut batu Tambang Breksi berjumlah 10 orang, dan bertambah menjadi 60 orang berprofesi sebagai pedagang kuliner setelah Batu Breksi menjadi Taman Wisata Tebing Breksi. selain itu, sebelum menjadi Taman Wisata masyarakat Desa Sambirejo yang berprofesi sebagai supir Truk Batu Breksi berjumlah 10 orang, namun setelah
Batu Breksi menjadi Taman Wisata Tebing Breksi pekerja bertambah dengan jenis pekerjaan yaitu, 40 orang sebagai pedagang kaki lima, 95 orang sebagai supir jeep, 25 orang sebagai penyedia jasa photobooth, 23 orang penyedia jasa ATV, 20 orang sebagai pengelola Balkondes, 20 orang sebagai pekerja bangunan/pemahat, dan 5 orang sebagai penyedia jasa foto.

Dampak terhadap solidritas masyarakat

Keberadaan Taman Wisata Tebing Breksi berdampak terhadap solidaritas masyarakat Desa Sambirejo, karena dengan adanya aktivitas wisata di Taman Wisata Tebing Breksi menjadikan masyarakat memiliki inisiatif untuk membentuk suatu komunitas-komunitas untuk mendukung pengembangan Taman Wisata Tening Breksi. Solidaritas masyarakat merupakan salah satu moto pengelolaan Tebing Breksi, yang tidak hanya membentuk komunitas-komunitas 
pendukung kegiatan wisata namun juga untuk menjaga kerukunan antar masyarakat terutama masyarakat yang terlibat dalam aktivitas wisata.

\section{Dampak terhadap nilai sosial}

Perbedaan nilai sosial yang dibawa oleh wisatawan tentunya akan memberikan dampak terhadap transformasi nilai sosial suatu masyarakat. Seperti yang terjadi di Desa Sambirejo

saat ini mulai terjadi perubahan transformasi nilai sosial yang ada di masyarakat.

Keberadaan Taman Wisata Tebing Breksi berdampak terhadap nilai sosial yang meliputi, gaya bahasa, gaya hidup, dan perilaku masyarakat. Saat ini masyarakat Desa Sambirejo terutama pelaku wisata di Taman Wisata Tebing Breksi sudah sangat mengalami perubahan nilai sosial dibandingkan dari saat Tebing Breksi masih menjadi tambang. Masyarakat yang dulunya tidak terbiasa dengan menggunakan alas kaki saat menambang saat ini sudah mulai menggunakan sepatu atau sandal, hal ini dikarenakan mereka menyesuaikan diri dan beradaptasi dengan lingkungan baru. Selain itu perubahan gaya bahasa yang dulu sangat kental dengan bahasa Jawa saat ini sudah mulai menggunakan bahasa formal, yaitu Bahasa Indonesia.

Dampak terhadap tata nilai merupakan dampak yang secara tidak langsung dapat berdampak terhadap masyarakat Desa Sambirejo, dimana masyarakat yang tidak berkomunikasi secara langsung dengan wisatawan juga dapat merasakan dampak dari gaya busana wisatwan yang datang ke Taman Wisata Tebing Breksi. Namun sejauh ini, dampak yang dibawa oleh wisatawan masih sangat baik karena membawa nilai positif terhadap masyarakat Desa Sambirejo.

Dampak yang terjadi dalam masyarakat cenderung positif, dimana masyarakat yang biasanya acuh terhadap penampilan mulai memperhatikan penampilan, dan mulai menerapkan komunikasi menggunakan Bahasa Indonesia, artinya dampak perubahan tata nilai sosial yang terjadi adalah positif.

\section{Dampak Ekonomi}

Dampak terhadap pendapatan masyarakat

Keberadaan Taman Wisata Tebing Breksi memberikan dampak yang sangat baik untuk pendapatan masyarakat Desa Sambirejo. Hal ini ditandai dengan tingkat kunjungan wisatawan yang selalu mengalami peningkatan setiap tahunnya. Pada tahun 2016 kunjungan wisatawan mencapai 500.000 pengunjung, di tahun 2017 mencapai 800.000 ribu pengunjung, dan di tahun 2018 kunjungan wisatawan meningkat pesat hingga mencapai 1.2 juta wisatawan. Pengelola Taman Wisata Tebing Breksi menargetkan 2 juta kunjungan wisatawan di tahun 2019.

Tabel 3

Tingkat kunjungan wisatawan

\begin{tabular}{ll}
\hline Tahun & Jumlah Kunjungan \\
\hline 2016 & 500.000 \\
2017 & 800.000 \\
2018 & 1.2 juta \\
\hline
\end{tabular}

Sumber : Data kunjungan Tebing Breksi (2019)

Tingkat kunjungan yang selalu mengalami peningkatan ini, memberikan dampak positif pada pendapatan masyarakat melalui usaha barang atau jasa yang diberikan untuk memenuhi kebutuhan wisatawan selama berkunjung. Usaha tersebut adalah usaha penyediaan makanan dan minuman, usaha jasa penyediaan spot foto, penyediaan jasa kendaraan jeep, dan bekerja sebagai anggota pokdarwis, pengelola, petugas parkir, petugas retribusi, petugas keamanan.

Keberadaan Taman Wisata Tebing Breksi yang sudah banyak menarik minat kunjungan wisatawan ini tentunya memberikan dampak terhadap peningkatan pendapatan masyarakat Desa Sambirejo. Berdasarkan temuan penelitian dan analisis data yang telah dilakukan, dinyatakan bahwa keberadaan aktivitas wisata di Taman Wisata Tebing Breksi dan meningkatnya tingkat kunjungan wisatawan memberikan dampak terhadap peningkatan pendapatan masyarakat Desa Sambirejo. 
Meningkatnya kunjungan ke Taman Wisata Tebing Breksi menjadikan pendapatan masyarakat bertambah, yaitu melalui retribusi tiket masuk dan parkir, tidak hanya dari retribusi tiket masuk dan parkir, namun juga dari aktivitas wisatawan menyewa penyedia jasa spot foto, jasa makanan dan minuman, jasa Jeep, dan jasa ATV juga memberikan dampak terhadap peningkatan pendapatan masyarakat Desa Sambirejo yang berkerja di Taman Wisata Tebing Breksi.

Dampak terhadap kesempatan kerja masyarkat

Keberadaan Taman Wisata Tebing Breksi menganut pola pengembangan berbasis masyarakat atau Community Bassed Tourism
(CBT), sehingga memberikan kesempatan yang sangat luas untuk masyarakat Desa Sambirejo untuk menjadi pelaku pariwisata di Wisata Taman Tebing Breksi. Taman Wisata Tebing Breksi mampu memberikan kesempatan kerja bagi masyarakat dalam sektor pariwisata setelah Tebing Breksi diresmikan sebagai destinasi wisata. Karena pengembangan Tebing Breksi sebagai destinasi wisata merupakan inisiatif masyarakat dengan tujuan untuk menopang kehidupan masyarakat yang kehilangan mata pencaharian karena pemberhentian aktivitas penambangan. Sehingga pengelola lebih mengutamakan masyarakat Desa Sambirejo untuk terlibat dalam pengembangan dan pengelolaan Taman Wisata Tebing Breksi.

Tabel 4

Jenis pekerjaan di Taman Wisata Tebing Breksi

\begin{tabular}{|c|c|c|c|}
\hline No & Jenis Pekerjaan & & Jumlah \\
\hline 1. & $\begin{array}{l}\text { Pengelola (pokdarwis, } \quad \text { petugas } \\
\text { lain-lain) }\end{array}$ & keamanan, kebersihan, retribusi, dan & 90 \\
\hline 2. & Pedagang Kuliner & & 60 \\
\hline 3. & Pedagang Kaki Lima & & 40 \\
\hline 4. & Supir jeep & & 95 \\
\hline 5. & Fotobooth & & 25 \\
\hline 6. & Penyedia ATV & & 23 \\
\hline 7. & Balkondes & & 20 \\
\hline 8. & Pekerja bangunan & & 20 \\
\hline 9. & Fotographer & & 5 \\
\hline Jum & h total & & 378 \\
\hline
\end{tabular}

Selain mendapatkan pekerjaan baru, sebagian masyarakat juga memiliki usaha baru. Secara detail, dampak keberadaan Taman Wisata Tebing Breksi terhadap kesempatan memiliki usaha baru di Taman Wisata Tebing Breksi terdapat pada tabel berikut

Tabel 5

Daftar Usaha dan Jasa Baru

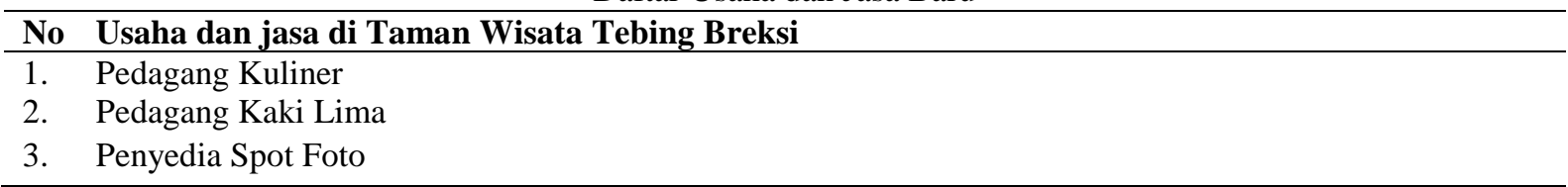

Sumber: Data primer, (2019)

Kesempatan membuka usaha ini diutamakan untuk masyarakat Desa Sambirejo yang dulunya bekerja sebagai penambang batu breksi dengan diberi fasilitas tempat usaha secara gratis, namun dengan catatan para pedagang harus berdagang masakan-masakan khas seperti opor ayam, soto betawi, soto lamongan, gulai, teriyaki dan lain sebagainya. Selain itu, kesempatan membuka usaha dagang juga diberikan kepada masyarakat asli Desa Sambirejo, untuk mendirikan usaha dagang yang disebut kaki lima dengan disediakan tampat usaha dengan catatan membayar sewa sesuai dengan ketentuan. Tidak hanya usaha makanan dan minuman, usaha jasa penyediaan spot foto 
juga diutamakan bagi masyarakat asli Desa Sambirejo yang ingin mencari nafkah di Taman Wisata Tebing Breksi. Penyedia jasa spot foto ini sangat diuntungkan, dimana penyedia jasa spot foto sama sekali tidak diharuskan membayar sewa, yang artinya keuntungan yang masuk sepenuhnya menjadi milik penyedia jasa spot foto.

\section{Dampak terhadap harga-harga}

Keberadaan Taman Wisata Tebing Breksi hingga saat ini belum menimbulkan dampak terhadap perubahan harga-harga dari usaha yang didirikan oleh masyarakat. Hal ini dikarenakan pengelola Taman Wisata Tebing Breksi menetapkan harga barang usaha dagang agar tidak terjadi kesenjangan harga dan kecemburuan sosial di masyarakat. Pematokan harga ini juga dilakukan pengelola guna untuk keberlanjutan usaha dagang masyarakat itu sendiri.

Keberadaan Taman Wisata Tebing Breksi memberikan dampak yang tidak telalu signifikan terhadap kenaikan harga baik harga makanan dan mnuman ataupun jasa, tidak seperti usaha makanan dan minuman di tempat wisata lainnya yang sebagian besar mematok harga tinggi demi keuntungan. Hal ini di karenakan aktivitas wisata di Taman Wisata Tebing Breksi menjual produk dengan harga standar namun tetap membantu pendapatan masyarakat, dan yang sangat penting pengelola memiliki tujuan agar usaha dagang yang didirikan masyarakat bertahan lama atau berkelanjutan. Selain harga terhadap jasa makan dan minuman yang standar, ternyata keberadaan Taman Wisata Tebing Breksi memberikan dampak harga terhadap penjualan dan persewaan tanah.

Dampak terhadap distribusi manfaat / keuntungan

Pengembangan Taman Wisata Tebing Breksi dengan pola pengembangan berbasis masyarakat, tentunya banyak memberikan dampak yang positif terhadap masyarakat Desa Sambirejo. Dampak distribusi manfaat / keuntungan yang dirasakan masyarakat Desa Sambirejo dari keberadaan aktivitas wisata di Taman Wisata Tebing Breksi adalah terbentuknya badaan pengelola keuangan desa yang disebut BUMDES atau Badan Usaha Milik Desa. Terbentuknya BUMDES ini tentunya memberikan manfaat/ keuntungan bagi masyarakat Desa Sambirejo, dimana masyarakat Desa Sambirejo sangat terbantu dengan adanya BUMDES di Desa Sambirejo, yaitu masyarakat Desa Sambirejo lebih mudah mendapatkan layanan simpan pinjam melalui BUMDES. Manfaat dan keuntungan yang timbul dari keberadaan Taman Wisata Tebing Breksi sangat berdampak positif terhadap manfaat / keuntungan masyarakat dari terbentuknya Badan Usaha Milik Desa (BUMDES) di Desa Sambirejo.

Dampak terhadap kepemilikan dan kontrol

Dalam pengembangannya, pengelola Taman Wisata Tebing Breksi menggunakan pola pengembangan Community Based Tourism (CBT) dan hingga saat ini belum ada investor yang masuk dalam pengelolaan dan pengembangan Taman Wisata Tebing Breksi, hal ini dikarenakan Pengelola Taman Wisata Tebing Breksi sangat mempertimbangkan kesejahteraan masyarakat yang bekerja di Taman Wisata Tebing Breksi, hal ini dikarenakan jika ada investor yang masuk, kecil kemungkinan bagi masyarakat Desa Sambirejo untuk terlibat didalam pengelolaan dan pengembangan Taman Wisata Tebing Breksi.

Pengelola Taman Wisata Tebing Breksi berkeinginan agar supaya Taman Wisata Tebing Breksi ini bertahan sampai ke generasi-generasi penerus. Pengelolaan yang saat ini diterapkan sangat menguntungkan masyarakat Desa Sambirejo, dimana masyarakat sangat diutamakan dalam kepemilikan dan kontrol dalam pengembangan Taman Wisata Tebing Breksi, hal ini dikarenakan pengelola Taman Wisata Tebing Breksi penuh pertimbangan terhadap kepemilikan dan kontrol untuk menerima investor sehingga sampai saat ini belum ada investor yang masuk ke dalam pengembangan Taman Wisata Tebing Breksi. 
Hasil temuan penelitian di lapangan, peneliti menemukan fakta bahwa dalam kepemilikan dan kontrol Taman Wisata Tebing Breksi sepenuhnya merupakan milik pengelola Taman Wisata Teing Breksi dan masyarakat lokal Desa Sambirejo. Dimana pengelola Taman Wisata Tebing Breksi dan Seluruh masyarakat Desa Sambirejo berhak ikut serta dalam mengelola Taman Wisata Tebing Breksi serta memiliki keluasan dalam kepemilikan dan kontrol Tebing Breksi dibawah pengawasan dan pengarahan dari Kelompok sadar wisata (Pokdarwis) Tlatar Seneng.

Dampak terhadap pembangunan pada umumnya

Berkembangnya Tebing Breksi menjadi destinasi wisata di Desa Sambirejo juga berdampak terhadap pembangunan-pembangunan pada umumnya, yaitu dengan dibangunnya jalan utama yang dulunya sudah rusak dan sempit saat ini Tebing Breksi yang sudah dibangun lebih bagus dan lebih lebar dari sebelumnya. Dengan adanya pembangunan jalan utama ini memberikan kenyamanan terhadap masyarakat Desa Sambirejo, selain juga memudahkan akses untuk menjangkau Taman Wisata Tebing Breksi. Hal ini memberikan bukti bahwa keberadaan Taman Wisata Tebing Breksi memberikan dampak sosial terhadap masyarakat Desa Sambirejo, dimana semua masyarakat baik yang terlibat langsung dalam aktivitas wisata maupun yang tidak terlibat sekalipun dapat menikmati pembangunan infrastruktur berupa jalan utama Desa Sambirejo, dan masyarakat Desa Sambirejo juga mulai dilatih untuk penyediaan homestay, dan Balai Ekonomi Desa (Balkondes).

Dampak terhadap pendapatan pemerintah

Keberadaan Taman Wisata Tebing Breksi tidak hanya berdampak terhadap masyarakat Desa Sambirejo, namun juga memberikan dampak terhadap pendapatan pemerintah, terutama Pemerintah Desa Sambirejo. Dimana Desa Sambirejo memiliki BUMDES sebagai pengawas aktivitas wisata Taman sudah bagus dan lebih lebar, karena aksesibilitas merupakan hal terpenting dari sebuah pengembangan destinasi wisata untuk memudahkan wisatawan mencapai destinasi.

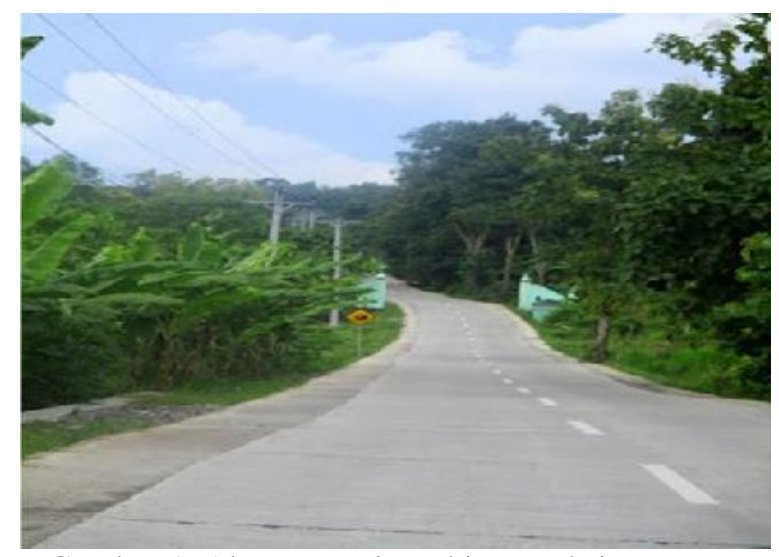

Gambar 1. Akses menuju Tebing Breksi yang sudah dibangun

Sumber : Dokumentasi pribadi 2019

Gambar 1 diatas, merupakan pembangunan infrastruktur jalan menuju Taman Wisata Wisata Tebing Breksi.

Keberadaan Taman Wisata Tebing Breksi memberikan dampak terhadap pendapatan Pemerintah Desa Sambirejo sebesar 25\% setiap minggunya dari pendapatan Taman Wisata Tebing Breksi. Jadi retribusi yang masuk ke kas desa tidak masuk setiap bulan namun setiap satu minggu sekali sebesar 25\% dari pendapatan Taman Wisata Tebing Breksi. Tarif retribusi di Taman Wisata Tebing Breksi mulai diberlakukan pada bulan Januari 2019, dimana harga tiket masuk sebesar Rp. 5000,- untuk wisatawan nusantara atau lokal, sedangkan untuk wisatawan asing tarif tiket masuk sebesar Rp. 10.000,-. Wisatawan yang berkunjung ke Taman Wisata Tebing Breksi sebelumnya tidak dikenakan tarif masuk/gratis dan wisatawan hanya dianjurkan untuk membayar dengan sukarela.

Pengelola Taman Wisata Tebing Breksi hanya memberikan tarif untuk parkir kendaraan untuk motor sebesar Rp. 2000,untuk mobil sebesar Rp. 5000, Minibus sebesar Rp. 15.000, dan untuk Bus besar sebesar Rp. 25.000. Setelah tarif retribusi 
diberlakukan pada bulan Januari 2019, pendapatan pengelolaan Taman Wisata Tebing Breksi cukup mampu untuk memberikan dampak terhadap pendapatan Pemerintah Desa Sambirejo.

Setelah penetapan tarif retribusi pengelola melakukan perundingan dengan BUMDES untuk mendapatkan kesepakatan besar pendapatan yang masuk ke BUMDES. Kesepakatan antara Pengelola Taman Wisata Tebing Breksi dengan BUMDES ditetapkan bahwa pendapatan yang masuk ke BUMDES dari pengelolaan Taman Wisata Tebing Breksi adalah sebesar 25\%. Pendapatan yang masuk ke BUMDES kemudian dibagi menjadi 2, yaitu $60 \%$ untuk PAD desa, dan $40 \%$ digunakan untuk operasional BUMDES.

\section{SIMPULAN}

Kesimpulan yang diambil dari dampak keberadaan objek wisata Tebing Breksi terhadap kehidupan ekonomi masyarakat Desa Sambirejo berdasarkan kesempatan kerja dan peluang usaha adalah: (1) Kesempatan kerja dan peluang berusaha semakin tinggi sehingga tingkat pengangguran di masyarakat semakin berkurang; (2) Pendapatan masyarakat bertambah, karena selain pendapatan dari mata pencaharian utama sebagai petani, masyarakat juga mendapat tambahan pendapatan melalui pekerjaan sampingan sebagai pemandu pariwisata maupun pengusaha sektor pariwisata seperti homestay dan rumah makan; (3) Dampak terhadap kepemilikan lokal semakin tinggi, karena sumber daya yang dikuasai masyarakat saat ini semakin produktif serta dikelola masyarakat untuk masyarakat sendiri. Dengan sistem pariwisata berbasis masyarakat atau Community Bassed Tourism (CBT); (4) Pengembangan pariwisata dapat memacu percepatan pengembangan desa pada umumnya seperti jalan, penerangan, air bersih dan lain-lain; (5) Meningkatnya harga-harga kebutuhan masyarakat yang diakibatkan oleh kegiatan pariwisata sampai saat ini belum pernah dirasakan oleh masyarakat, justru yang terjadi adalah semakin terangkatnya nilai jual produk-produk lokal misalnya produk kerajinan batik dan oleh-oleh.

Dalam penelitian ini diketahui bahwa keberadaan Taman Wisata Tebing Breksi membawa perubahan yang sangat beragam terhadap sosial masyarakat Desa Sambirejo. Perubahan yang terjadi tersebut tentunya terdapat sisi positif. Sisi positifnya ialah munculnya struktur mata pencaharian baru di masyarakat yaitu mata pencaharian di sektor pariwisata. Masyarakat lokal yang dulunya masyarakat yang mayoritas sebagai petani, buruh, penambang dan lainnya setelah keberadaan Taman Wisata Tebing Breksi dapat bekerja maupun berwirausaha di sektor pariwisata. Keberadaan Taman Wisata Tebing Breksi membawa transformasi tata nilai secara positif, masyarakat yang dahulu memiliki gaya hidup, gaya bahasa, dan perilaku yang medok sekarang menjadi masyarakat yang mulai memperhatikan kerapian, kenyamanan saat bertemu pengunjung, dan penggunaan Bahasa Indonesia.

Dari analisis yang dihasilkan dalam penelitian ini, maka ada beberapa saran yang dapat peneliti berikan kepada pihak baik Pengelola Taman Wisata Tebing Breksi maupun Pemerintah Desa Sambirejo: (1) Mempertahankan pola pengembangan yang berbasis masyarakat untuk menjaga taraf hidup mansyarakat Desa Sambirejo menjadi lebih baik; (2) Menciptakan daya tarik yang mampu membuat wisatawan lebih lama tinggal di Taman Wisata Tebing Breksi atau atraksi yang mampu menambah Length of Stay wisatawan; (3) Menghidupkan kebudayaan yang mampu menjadi identitas dari Taman Wisata Tebing Breksi Desa Sambirejo; (4) Mulai menerapkan sustainable tourism atau pariwisata berkelanjutan agar Taman Wisata Tebing Breksi mampu bertahan di tengah kemunculan destinasi-destinasi baru. 


\section{DAFTAR PUSTAKA}

Arjana, I.G.B. (2015). Geografi Pariwisata dan Ekonomi Kreatif. Jakarta: PT. Raja Grafindo Persada.

Darwan, D., Yunus, L., Fyka, S. A., \& Limi, M. A. (2019). Dampak Ekonomi Pengembangan Wisata Pulau Bokori Terhadap Masyarakat Lokal Bajo Di Kabupaten Konawe. Buletin Penelitian Sosial Ekonomi Pertanian Fakultas Pertanian Universitas Haluoleo, 21(1), 45-51.

Fyka, S. A., Yunus, L., Limi, M. A., Hamzah, A., \& Darwan, D. (2018). Analisis Dampak Pengembangan Wisata Pulau Bokori Terhadap Kondisi Sosial Ekonomi Masyarakat Bajo (Studi Kasus di Desa Mekar Kecamatan Soropia). Habitat, 29(3), 106-112.

Pitana, I. G \& Gayatri, I.P. (2005). Sosiologi Pariwisata. Yogyakarta : Andi

Sapta Nirwandar (2011) Pembangunan Sektor Pariwisata: Di Era Otonomi Daerah, diunduh dari http://www.scribd.com/doc/35092726/ 440-1257-Pembangunan-Sektor -Pariwisata.

Soekanto, S. (2005). Sosiologi Suatu Pengantar. Jakarta: Raja Grafindo Persada.

Sugiyono, 2014. Metode Penelitian Kuantitatif Kualitatif dan $R \& D$. Bandung: Alfabeta

Undang-Undang Republik Indonesia No. 10 Tahun 2009 Tentang Pariwisata

Wahyudy, S. N. (2019). Transformasi Budaya Tradisi Masyarakat Agraris Pada Generasi Muda: Analisis Transformasi Gendongan Lesung di Desa Wisata Kandri, Kecamatan
Gunung Pati, Kota

Semarang (Doctoral dissertation, UNNES).

Walgito, Bimo. 2002. Psikologi Sosial. Yogyakarta : Andi Yogyakarta

Widagdo, R \& Rokhlinasari, S. (2017). Dampak Wisata Religi Terhadap Perkembangan Ekonomi Masyarakat Cirebon. Al-Amwal, 9 (1).

http://www.kemenpar.go.id/post/siaran-perspengarusutamaan-jadikunci-sukses-pengembangan-sektor-par iwisata, diakses pada tanggal 15 April 2019.

\section{PROFIL PENULIS}

Mona Erythrea Nur Islami, merupakan dosen tetap di Sekolah Tinggi Pariwisata AMPTA Yogyakarta, bidang kajian antropologi pariwisata.

Id Scholar:

https://scholar.google.co.id/citations?hl=id\& user=EvmDZT8AAAAJ

Umiyati, alumni Sekolah Tinggi Pariwisata AMPTA Yogyakarta 